\title{
縮約と遡行による階層的生体リズム機構のモデル化
}

\author{
非会員 中尾 光之* 非会員 岡山 大* \\ 非会員 片山 統裕* 非会員 辛島 彰洋*
}

\section{Reduction and Retrospection Approach to Modeling of Hierarchical Biological Rhythms}

Mitsuyuki Nakao*, Non-member, Hiroshi Okayama*, Non-member, Norihiro Katayama*, Non-member,

Akihiro Karashima*, Non-member

Physiome inherently investigates hierarchical layers of biological system. In the post genome era, the number of layers should increase because possible mechanisms at molecular level are always referred to. However, biological modeling in the post genome era has to face unavoidable uncertainties in biological measurements and explosion of degree of freedom. An exhaustive modeling seems to be necessary to understand possible mechanisms underlying biological phenomena at every hierarchical level. However, simultaneously it looks like an impossible or reckless trial. In order to get rid of them, we propose a novel modeling strategy that integrates the top-down retrospection and bottom-up reduction modeling. Here, our strategy is applied to modeling of biological rhythms which is an appropriate system to study because of the penetration of rhythmic dynamics through all of the hierarchical layers.

キーワード : フィジオーム, 視交差上核, 分子時計機構, SCN 振動体, 非 SCN 振動体

Keywords : physiome, suprachiasmatic nucleus ( $\mathrm{SCN})$, molecular clock mechanism, $\mathrm{SCN}$ oscillator, nonSCN oscillator

\section{1. はじめに}

生体システムの特質からフィジオームの対象はいくつか の階層にわたることになる。これらの階層は多くの場合「繰 り込まれる」こともなく，階層毎に個別の扱いが必要とな る。ポストゲノム時代においては，扱う生体システムのレ ベルによらず，常に分子レベルのメカニズムを参照するこ とが求められることから問題はさらに困難さを増してい る。これらを解決するツールとして数理的なモデリングの 役割が期待されている。システム生物学の流行もこのよう な流れの中に位置づけられよう。しかしながら，分子レベ ルの計測技術の発展により分子レベルのモデリングに必要 な情報は蓄積されてきているものの未だ十分ではないし， 精度的にも必ずしも高いとはいえない場合が多い。同時に， このような状況は分子レベルに限定されるものではなく, 生体システムを構成する各階層において共有される特質で もである。従って, 多くの階層を射程に入れたモデリング をナイーブに行ってしまうと，単に不確定性を積み重ねた だけで，必要な信頼性を得られないことにもなりかねない。 また，自由度が高すぎて見通しのよいメカニズムの理解が

\footnotetext{
東北大学大学院情報科学研究科

干980-8579 宮城県仙台市青葉区荒巻字青葉 6-3-09 GSIS, Tohoku University

6-3-09, Aobayama, Aoba-ku, Sendai 980-8579
}

実現されないことも予想される。研究者の中には, このよ うな問題意識から, 分子レベルまで遡って何かを読み解き たいという欲望を自らに禁じるものもある。著者はそのよ うな倫理的振舞いからは遠くにいるが，何らかの戦略が必 要だとは感じている。

生物の階層性を問題にするとき生体リズム機構は都合の 良い研究対象である。なぜなら, 日周期のリズムが分子か ら行動まですべての階層を貫いて存在しているからであ る。生体リズムは行動学的研究が従来から盛んに行われて きており, それらによってもたらされた知見を基に, 我々 はヒトの生体リズム機構をモデル化してきた ${ }^{(1) \sim(3)}$ 。一方で, 生体リズムの分子生物学的な研究により，時計遺伝子群お よびそれらの間の相互作用が明らかにされてきており(4), 分 子時計機構のモデルも数多く生み出されている(5)。我々は階 層的リズム機構をモデル化する戦略として「縮約と遡行」 からなる枠組みを提案している (図 1) (6)。これは, 行動学 的なモデルから出発した我々の出自と大いに関係してい る。基本的には下位の階層のモデルが持つ不確定性を, 上 位の階層のダイナミクスを「遡行的に」読み解くことによ って補おうとするものである。この過程には「遡行」を助 けるために下位のモデルのダイナミクスを「縮約」する必 要がある。このような「縮約と遡行」を，階層を行き来し ながら適用することによってモデル化を実現しようとする 


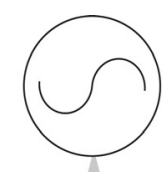

SCN model

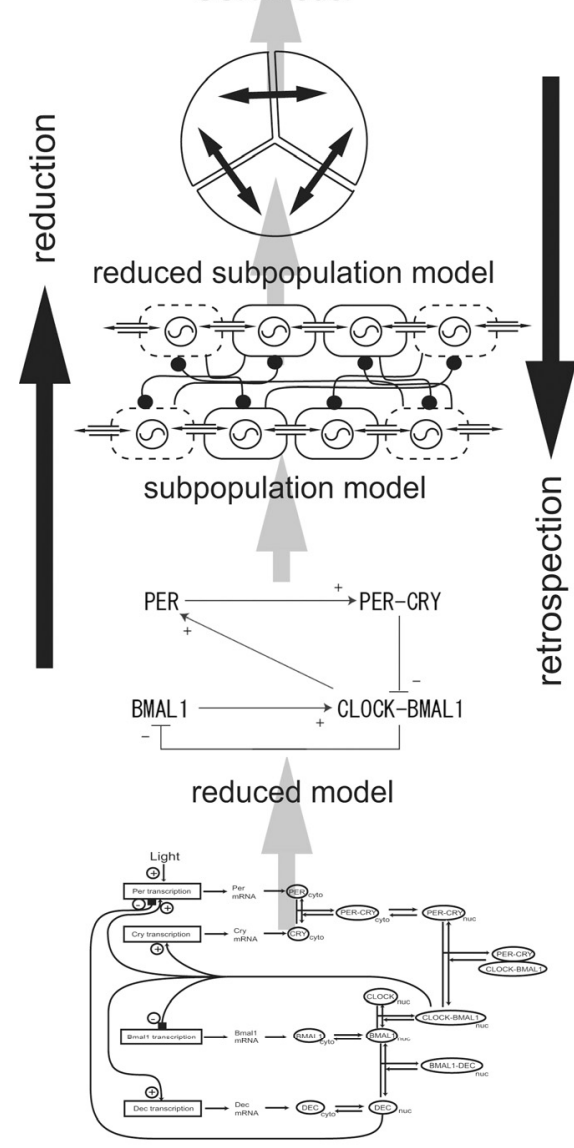

detailed model

図 1 縮約と遡行による階層的生体リズム機構の モデリング

Fig. 1. Reduction and retrospection approach to modeling of hierarchical biological rhythm

ものである。この戦略に基づくモデル化は未だ道半ばであ るが，階層的生体システムのモデル化の一つの試みとして 紹介する。問題意識を共有する研究に何か資するものがあ れば幸いである。

\section{2. 階層的生体リズム機構のモデル化}

生体リズム機構は図 1 に示すように分子レベル, 細胞レ ベル，ペースメーカ細胞の集積する視交差上核 ( $\mathrm{SCN}$ ) や末 梢器官レベル, 行動レベルと多くの階層からなっている。 以下では，分子レベルから行動レベルを目指したボトムア ップ的モデリング (縮約) と行動レベルからのトップダウ ン的モデリング（遡行）について説明する。

〈2.1〉 分子時計機構のモデル化とその縮約 現在相 当数の遺伝子が分子時計の生成に関わっていることが知ら れている(7)。中でも主要な遺伝子からなるネットワークを図 1 (最下段) に示寸。これは 10 数種類の変数からなる微分
方程式で記述される(9)。これでも多くの遺伝子の寄与が省略 されており 70 変数程度のモデルも提案されている ${ }^{(8)}$ 。モデ ルの妥当性は遺伝子発現レベルや対応したタンパク質濃度 の振動と位相関係から確かめた。さらに光刺激の効果を模 擬して位相反応曲線を求め実験データと比較した。これら はいずれもモデルが生成した振動ダイナミクスが実際の分 子時計の振舞いを再現していることを示唆するものであつ た ${ }^{(9)}$ 。これを分子レベルのモデルと考え, 本質的なダイナミ クスを保存しながら変数を 4 にまで縮約したものが図 1 (下 から 2 段目）に掲げたモデルである(9)。分子時計機構モデル の 15 変数のうち, ほぼ同位相で振動している時計遺伝子群 Per, Cry, Dec を一つの変数 PER で代表させ, 時計遺伝子 Bmal1 を変数 BMAL1 で代表させた。併せて, mRNA と対 応するタンパク質を区別しないで表現した。さらに転写制 御と, タンパク-タンパク相互作用を表現するために 2 変数

PER-CRY とCLOCK-BMAL1 を加えた。縮約した表現を以 下に示す。

$$
\begin{aligned}
& \frac{d P E R}{d t}=S_{1} \frac{C B}{K_{1}+C B}-D_{1} \frac{P E R}{L_{1}+P E R}-D_{0} P E R \\
& \frac{d P C}{d t}=S_{2} \frac{P E R}{K_{2}+P E R}-D_{2} \frac{P C}{L_{1}+P C}-D_{0} P C \\
& \frac{d B M A L 1}{d t}=S_{3} \frac{K_{3}}{K_{3}+C B}-D_{3} \frac{B M A L 1}{L_{3}+B M A L 1}-D_{0} B M A L 1 \\
& \frac{d C B}{d t}=S_{4} \frac{B M A L 1}{K_{4}+B M A L 1}-V_{1} P C \cdot C B-D_{4} \frac{C B}{L_{4}+C B}-D_{0} C B
\end{aligned}
$$

縮約によって元のダイナミクスが保存されていることは図 3 に示すような振動位相関係と位相反応曲線によって確認 している。位相反応は 1 時間だけ PER の産生率を上昇させ て求めた。ここに, $S_{1}=0.97, S_{2}=1.1, S_{3}=2.6, S_{4}=0.54, S_{5}=0.70$, $D_{0}=0.0099, \quad D_{1}=0.70, \quad D_{2}=0.38, \quad D_{3}=1.9, \quad D_{4}=0.19, \quad L_{1}=0.30$, $L_{2}=0.010, \quad L_{3}=0.30, \quad L_{4}=0.050, \quad K_{1}=0.75, \quad K_{2}=2.1, \quad K_{3}=0.85$, $K_{4}=0.030$ である。

以上の縮約プロセスは分子レベルのモデルのダイナミク スの主要な性質を保存しながら自由度を低減しており, 最 終的に SCN モデルにおける自由度の増大を防いでいる。力 学的には縮約は多様体理論に基づき行われなくてはならな いが，その適用範囲は限られている。ここで行ったような 発見的な方法やよく性質の知られた少自由度の力学系を利 用することも実際的な方法としての意味があると考える。

時計遺伝子を含む転写一翻訳ループはさらに細胞内シグ ナル伝達系, シナプス結合やギャップ結合などの細胞間の 相互作用へと開かれている。これらのメカニズムを縮約モ デルヘと組み入れ細胞レベルのモデルが完成する。ペース メーカ細胞モデルを結合すれば SCN モデルを構成すること ができる。実際の SCN では, ギャップ結合, シナプス結合, ペプタイドの拡散などにより細胞同士が結合されていると 考えられる。細胞内シグナル伝達系や細胞間の相互作用の モデル化の詳細についてはさらに広範な検討が必要であ る。図 3 にPER と BMAL1 を単に拡散させて得られた 10,000 


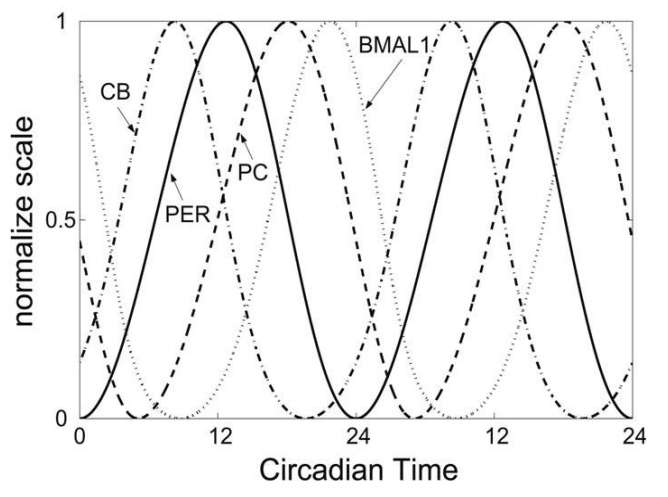

(a) 縮約モデルの振動波形

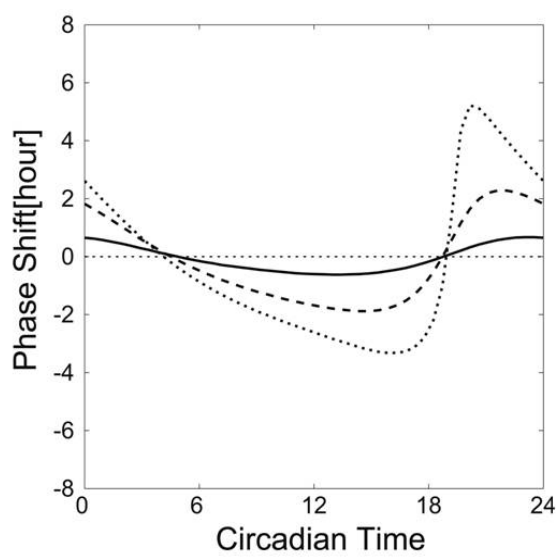

(b) 縮約モデルの位相反応曲線( ${ }^{(9)}$ 刺激強度 : 実線 0.1 , 破線 0.3 , 点線 0.5

図 2 縮約モデルの振動と位相反応曲線（PRC）

Fig. 2. Oscillations and phase response curve (PRC) of reduced model

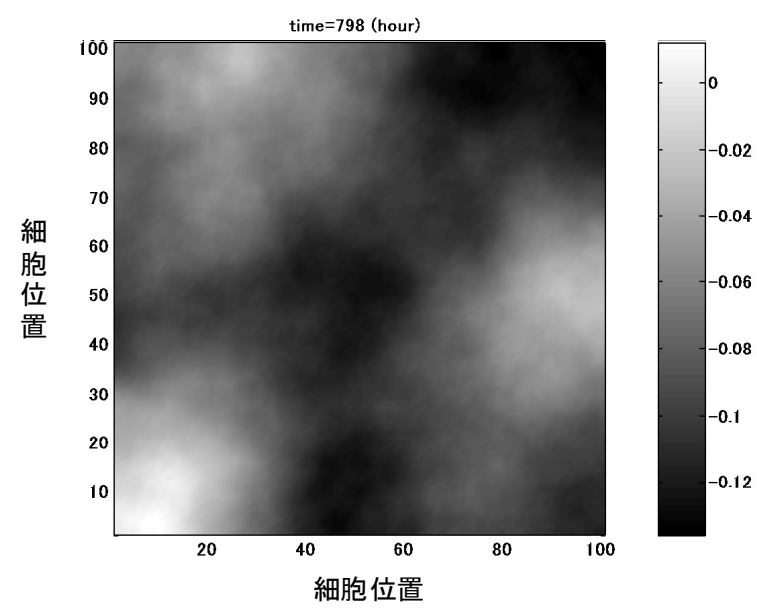

図３ＳCN モデルの格子点に配置された細胞振動の 位相差分布のスナップショット ${ }^{(9)}$

Fig. 3. Snap-shot of spatial distribution of phase difference between cellular oscillations

個の細胞振動間の位相差（適当な 1 つの細胞の振動を基準 として計算した）の空間分布を示す（拡散定数： $D_{P E R}=1$, $\left.D_{B M A L 1}=20\right)^{(9)}$ 。いくつかの同期的な集団が形成されている

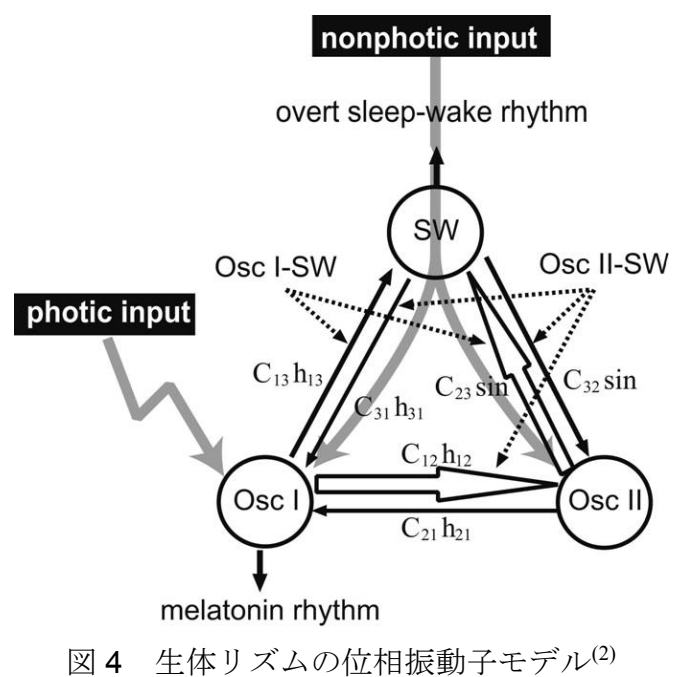

Fig. 4. Coupled phase oscillator model of biological rhythm

様子が分かる。ここでは，この単純な結果を示すことで分 子レベルのモデルからボトムアップ的に SCN のモデルが構 成されるプロセスを示すに留める。これが行動レベルでの $\mathrm{SCN}$ 振動子に対応することに注意してほしい。

〈2·2〉行動レベルのモデルとその遡行的解䣋 ここ では行動レベルの生体リズム機構のモデルについて述べ る。これらは分子レベルでの時計機構とは無関係に構築さ れたものである。また, 分子レベルの時計機構が集積され たシステムが最大限縮約された姿であるとも言えよう。未 だ議論はあるが，行動レベルでは 2 つの日周振動子が生体 リズムを支配しているとする考えに立って我々はモデル化 を行ってきた。モデルは SCN に支配された振動子（Osc I） と非 SCN の時計機構を総合した振動子（Osc II），および実 際の睡眠一覚醒パターンを表現する振動子（Osc SW）の 3 つの位相振動子からなっている（図 4）(1)(3)。

$$
\begin{aligned}
& \dot{\zeta}=1 \\
& \dot{\theta}_{1}=\omega_{1}+C_{21} h_{21}\left(\theta_{2}-\theta_{1}\right)+C_{31} h_{31}\left(\theta_{3}-\theta_{1}\right) \\
& +1^{L}(\zeta) \delta\left(\theta_{3}-1 / 3\right) f\left(\theta_{1}\right)+1^{W}\left(\theta_{3}\right) \delta\left(\zeta-\zeta^{L}\right) f\left(\theta_{1}\right) \\
& \dot{\theta}_{2}=\omega_{2}+C_{12} h_{12}\left(\theta_{1}-\theta_{2}\right)+C_{32} \sin 2 \pi\left(\theta_{3}-\theta_{2}\right) \\
& \dot{\theta}_{3}=\omega_{3}+C_{13} h_{13}\left(\theta_{1}-\theta_{3}\right)+C_{23} \sin 2 \pi\left(\theta_{2}-\theta_{3}\right) \\
& \text { under free-run situation } \\
& \theta_{3}=\omega_{0}+\phi_{s} \\
& \text { under rest-activity schedule }
\end{aligned}
$$

ここに, $\omega_{1}(=0.97), \omega_{2}(=0.81), \omega_{3}(=0.81), \omega_{0}(=1)$ は Osc I, II, SW の角速度, および休息一活動スケジュールの角速 度，をそれぞれ表す。 $\theta_{1} ， \theta_{2} ， \theta_{3} \in[0,1]$ はそれぞれ Osc I， II, SW の位相を表す。 $\zeta ， \zeta^{L}$ は明暗サイクルの位相および 明期の開始位相を示す。 $1^{L} ， 1^{W}$ は明期および活動期間に 1 となり, その他は 0 となる関数である。 $f$ は Osc I の PRC で ある。更なる詳細については文献( 1)を参照してほしい。こ のモデルの特徵は光のみならず Osc SW から Osc I および II への同調メカニズム（非光同調）を有している点である。 
これは Hashimoto らの実験結果に基づいて構成された ${ }^{(10)}$ 。 モデルにおいては，彼らの結果を再現するために，相互作 用として図 5(a)に示すように不連続性を有する (位相差に関 する）周期関数を導入した。これは睡眠一覚醒リズム（非 $\mathrm{SCN}$ 振動子）とメラトニンリズム（SCN 振動子）の位相差 と位相変化の関係を再現する上で本質的であった。モデル によるシミュレーション結果を図 5(b)に示す。位相差 0.5 (半 周期）で位相変化方向が反転しており，実験結果とも一致 している。位相振動子は非線形振動子としての実体からは 離れているが，位相縮約の過程で不連続な相互作用が導出 されることは考えにくい。しかしながら，全く異なる立場 から提案された睡眠一覚醒リズムのモデルにおいても，サ ークルマップの意味で同様な性質が見出されたことから， 不連続な相互作用は生物学的なダイナミクスの本質を写し 取っている可能性がある(11)。

位相振動子間の相互作用は結合される振動子の力学的性 質と相互作用の形態によって決まると考えられる。もしそ うなら, 上述の睡眠一覚醒リズムの位相変化の不連続な性

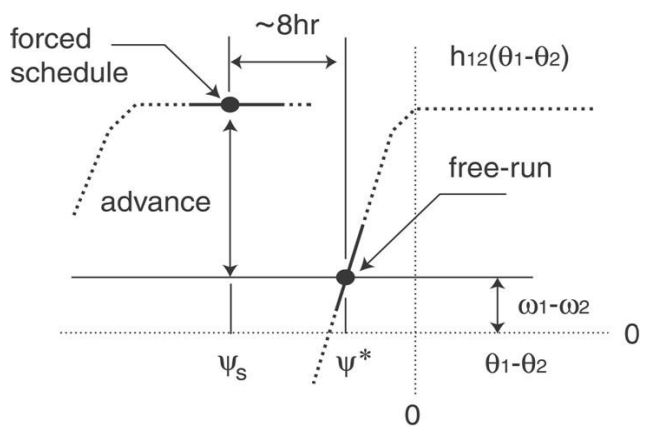

(a) 位相振動子モデルにおけるOsc Iから Osc II への相互作用関数 $h_{12}$ (点線)

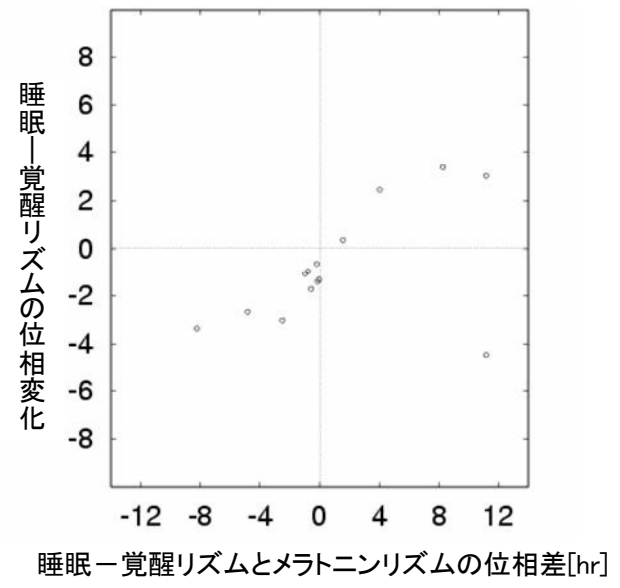

(b) 睡眠一覚醒リズム位相変化のメラトニンリズムと睡眠一覚醒 リズムの位相差依存性

図 5 位相振動子モデルの相互作用関数と睡眠一覚醒 リズムの位相変化のシミュレーション (1)

Fig. 5. An interaction function of phase oscillator model and simulated time evolution of sleep-wake phase dependent on phase difference between sleep-wake rhythm and melatonin rhythm
質は行動レベルでの SCN および非 SCN 振動子の力学的性質 を表出させていると言えるのではないだろうか。そこで, Van del Pol 振動子を速度で結合した生物リズムモデルの古 典である Kronauer のモデル(12)を考える。

$$
\begin{aligned}
& k^{2} \frac{d^{2} x}{d t^{2}}+k \mu_{x}\left(-1+x^{2}\right) \frac{d x}{d t}+\omega_{x}^{2} x+F_{y x} k \frac{d y}{d t}=0 \\
& k^{2} \frac{d^{2} y}{d t}+k \mu_{y}\left(-1+y^{2}\right) \frac{d y}{d t}+\omega_{y}^{2} y+F_{x y} k \frac{d x}{d t}=0
\end{aligned}
$$

ここに, $k=24 / 2 \pi, \omega_{x}=0.99, \omega_{y}=0.92, \mu_{x}=\mu_{y}=0.1, F_{y x}=$ $-0.04, F_{x y}=-0.16$ である。X 振動子が SCN 振動子に, Y が 非 SCN にそれぞれ対応している。この振動子系の引き込み の様子とそこへの再同調のダイナミクスを厳密に求めるこ とは困難であるが，近似的には摂動法を使って議論するこ とができる。それによれば，パラメータの值によらず同位 相および逆位相近傍での引き込み解が存在し, 同位相引き 込みが安定であり，逆位相は不安定であることが分かって いる(13)。この場合の両者の位相差はその正弦関数に従って 推移する。この関係は, 睡眠一覚醒リズムの位相変化（図 5(b)）と同一視できることから, 不安定な逆位相同期解近傍 では睡眠一覚醒リズム位相の変化は連続であることが示唆 される。これらの性質は結合形態を速度から拡散に変えて も同様であった。異なる構造を持つ振動子ではそうなると は限らない。実際, BVP (Bonhoeffer-Van del-Pole) 振動子で は逆位相同期解が安定になるパラメータ領域があることが 示されている(13)。先に述べたように, Hashimoto らは睡眠一 覚醒リズムとメラトニンリズムが逆位相関係にある時, 前 者の位相変化の方向が反転することを示し, 我々は位相振 動子モデルにおいてこれが SCN 振動子から非 SCN 振動子へ の不連続な相互作用によるものではないかと予想した。力 学的実体を有する振動子系の解析から SCN 振動子や非 SCN 振動子の構造や相互作用の形態を推定することができるか もしれない。さらに, それぞれは細胞レベルの振動機構の 集合体であることから, 細胞振動子の力学的性質や細胞レ ベルの結合形態をメタレベルから制約しているだろう。こ れをボトムアップ的に構築された縮約モデルを参照しなが ら分子レベルに向かって行うのが「遡行的アプローチ」で ある。

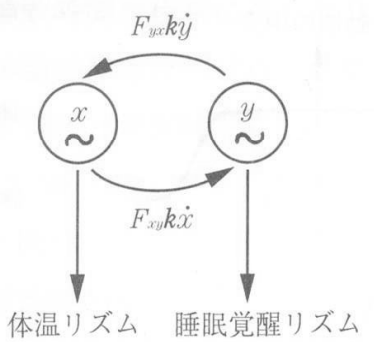

図 6 生体リズムの結合振動子モデル(12)

Fig. 6. Coupled oscillator model of biological rhythm 


\section{3. むすび}

本稿では, 生体リズム機構を対象として階層的な生体シ ステムをモデル化する試みについて述べた。「縮約と遡行」 という戦略は生体システムが階層構造であることを前提と している。しかしながら, 生体システムでは, 分子レベル から一方向的に階層が積み重なっているわけではない。上 位から下位へ向けての再帰的な影響も考慮する必要がある だろう。さらなる一般化と精密化については今後の課題と したい。

網羅的なシミュレーションの流行は計算機能力の向上に 支えられている。これが生物理解への近道であるとする考 えからは，少自由度系の見通しのよさに頼るアプローチは 旧弊な態度に映るだろう。しかしながら我々の理解能力が 少自由度に限られるならそれに適合した簡略化が必要なの ではないだろうか。その過程にこそ本質的な数理的, 生物 学的洞察を費やす価值があるのではないか。この意味から は, ポストゲノム時代といっても何か新しい問題が生まれ ているわけではなく, より本質的な視座が要求されるよう になっただけかもしれない。

\section{謝 辞}

この研究の一部は東北福祉大学感性福祉研究所における 文部科学省の学術フロンティア推進事業による助成に拠つ ている。

(平成 19 年 7 月 20 日受付)

\section{文献}

(1) M. Nakao, K. Yamamoto, K. Honma, S. Hashimoto, S. Honma, N. Katayama, and M. Yamamoto : "A phase dynamics model of human circadian system”, J. Biol. Rhythms, Vol.17, pp.476-489 (2002)

(2) M. Nakao, K. Yamamoto, K. Honma, S. Hashimoto, S. Honma, N. Katayama, and M. Yamamoto : "Modeling interactions between photic and nonphotic entrainment mechanisms in transmeridian flights", Biol. Cybern., Vol.91, pp.138-147 (2004)

( 3 ) M. Nakao, K. Yamamoto, K. Honma, S. Hashimoto, S. Honma, N. Katayama, and M. Yamamoto : "Modeling photic and nonphotic entrainment mechanisms in human circadian system", In: Trends in Chronobiology Research, F Columbus, ed, pp.157-212, Nova Science Publishers, Inc., New York (2005)

(4) S. Reppert and D. Weaver : "Coordination of circadian timing in mammals", Nature, Vol.418, pp.935-941 (2002)

( 5 ) J. C. Leloup and A. Goldbeter : "Toward a detailed computational model for the mammalian circadian clock", Proc Natl Acad Sci USA, Vol.100, pp.7051-7056 (2003)

(6) M. Nakao : "Toward hierarchical modeling of biological clock mechanisms", Proc SICE Ann Conf 2005, pp.3531-3536 (2005)

( 7 ) H. R. Ueda, W. Chen, A. Adachi, H. Wakamatsu, S. Hayashi, T. Takasugi, M. Nagano, K. Nakahama, Y. Suzuki, S. Sugano, M. Iino, Y. Shigeyoshi, and S. Hashimoto : "A transcription factor response element for gene expression during circadian night”, Nature, Vol.418, pp.534-539 (2002)

(8) D. B. Forger and C. S. Peskin : "A detailed predictive model of the mammalian circadian clock", Proc Natl Acad Sci USA, Vol.100, pp.14806-14811 (2003)

(9) M. Nakao, Y. Nishimura, K. Aoki, and N. Katayama: "Modeling of the suprachiasmatic nucleus based on reduced molecular clock mechanisms", Proc. $26^{\text {th }}$ Ann. Conf. IEEE EMBS, pp.2897-2900 (2004)

(10) S. Hashimoto, K. Nakamura, S. Honma, and K. Honma : "Non-photic entrainment of human rest-activity cycle independently of the circadian pacemaker.", Sleep and Biol. Rhythms, Vol.2, pp.2897-2900 (2004)

(11) M. Nakao, K. Yamamoto, N. Katayama, and M. Yamamoto : "Formal similarity between the two process model and a coupled oscillator model", Abstracts of $17^{\text {th }}$ APSS Meeting, 0243E (2003)

(12) R. E. Kronauer, C. A. Czeisler, S. F. Pilato, M. C. Moore-Ede, and E. D. Weitzman : "Mathematical model of the human circadian system with two interacting oscillators”, Am J Physiol, Vol.242, R3-R17 (1982)

(13) 岡山 大・辛島彰洋・片山統裕・中尾光之：「結合振動子モデルの再 同調過程の解析」, 時間生物学, 12, p.69 (2006)

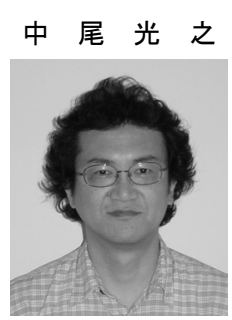

岡山大

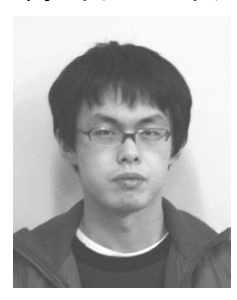

片 山 統 裕

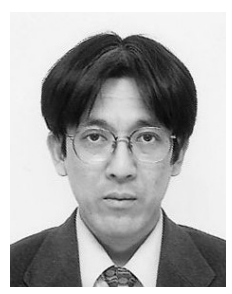

辛島 彰 洋

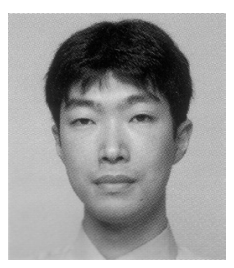

（非会員） 1956 年 7 月 12 日生。1984 年 3 月東 北大学工学研究科博士後期 3 年の課程修了。工 学博士。東京都老人総合研究所助手, 東北大学 工学部助手, 助教授, 同学大学院情報科学研究 科助教授を経て, 2004 年 4 月より同教授。現在 生体システムのモデリング研究に従事。

（非会員） 1983 年 1 月 31 日生。 2006 年 3 月東 北大学工学部情報工学科卒業。同年 4 月同大学 大学院情報科学研究科博士前期 2 年の課程入 学, 現在に至る。生体リズム機構のモデリング 研究に従事。

（非会員） 1967 年 8 月 7 日生。1996 年 3 月東 北大学大学院情報科学研究科博士後期 3 年の課 程修了。博士 (情報科学)。1993-1995 学術振 興会特別研究員。東北大学大学院情報科学研究 科助手を経て, 2003 年 4 月同研究科助教授。2007 年 4 月より准教授。神経生理学, 生物物理学, 生体信号処理の研究に従事。

（非会員） 1976 年 10 月 7 日生。 2004 年 3 月東 北大学大学院情報科学研究科博士後期 3 年の課 程修了。博士 (情報科学)。2004 年 4 月より東 北大学大学院情報科学研究科助手, 2007 年 4 月より同研究科助教。神経生理学および生体信 号処理の研究に従事。 